Review Articles

\title{
RCMV ALL-03 Model and Study of CMV Pathogenesis in Congenital Infection
}

\author{
${ }^{1}$ Ashwaq Ahmed Abdullah, ${ }^{2}$ Krishnan Nair Balakrishnan, \\ ${ }^{2}$ Yusuf Abba, ${ }^{3}$ Faez Firdaus Jesse Abdullah, ${ }^{1,2}$ Zeenatul Allaudin Nazariah, \\ ${ }^{1,2}$ Rasedee Abdullah, ${ }^{2}$ Noordin Mohamed Mustapha and ${ }^{1,2}$ Mohd-Azmi Mohd-Lila \\ ${ }^{1}$ Institute of Bioscience, Universiti Putra Malaysia, 43400, Serdang, Selangor D.E., Malaysia \\ ${ }^{2}$ Department of Pathology and Microbiology, Faculty of Veterinary Medicine, \\ Universiti Putra Malaysia, 43400, Serdang, Selangor D.E., Malaysia \\ ${ }^{3}$ Department of Veterinary Clinical Studies, Faculty of Veterinary Medicine, Universiti Putra Malaysia, 43400, Serdang, \\ Selangor D.E., Malaysia
}

Article history

Received: 11-03-2015

Revised: 09-07-2015

Accepted: 08-07-2015

Corresponding Author: Ashwaq Ahmed Abdullah and Moh-Azmi Mohd-Lila Institute of Bioscience, Universiti Putra Malaysia, 43400, Serdang, Selangor D.E., Malaysia

Department of Pathology and Microbiology, Faculty of

Veterinary Medicine, Institute of Bioscience, Universiti Putra Malaysia, 43400, Serdang,

Selangor D.E., Malaysia

Email: alalawiashwaq1@yahoo.com

Email: azmilila@gmail.com

\begin{abstract}
Cytomegalovirus (CMV) is one of the most commonly studied members of the Herpesviridae family. So far several strains have been identified but human CMV (HCMV) remains the most important due to its ability to infect humans and also cross the placenta causing neonatal infection and mortality. However, there are several limitations in the study of this strain which includes availability and use of model animals. Although strains such as Rhesus CMV (RhCMV), Guinea pig CMV (GPCMV) and Rat CMV (RCMV ALL-03) have been shown to cross the placenta and exhibit similar pathogenesis to HCMV, only RCMV ALL-03 can be conveniently used without much limitations as guinea pigs are resistant to antiviral drugs, while rhesus monkeys are seropositive, considered costly and have ethical use restrictions. We therefore propose the use of RCMV ALL-03 as a model for the study of CMV infection.
\end{abstract}

Keywords: Cytomegalovirus, Animal Model, Congenital Infection, Sensory Neural Hearing Defect (SNHD), Central Nervous System Abnormalitis

\section{Introduction}

Cytomegalovirus (CMV) is a member of herpesviridae family. Approximately, eight members of this family are well known to cause disease in humans. The differences between these 3 subfamilies lies in their genome sequences and virus biology such as host range, growth kinetics, tissue tropism and ability to transform cells (Pass et al., 2009; Roizman et al., 1981). CMV is classified as a beta virus because of its unique properties that involves its strict species specificity, salivary glands tropism and slow growth in the cell culture (Britt, 2008; Landolfo et al., 2003; Mocarski et al., 2007).

\section{Virus Structure and Genome Organization}

Like any other herpesvirus, CMV is an enveloped virus with an icosahedral virion (150-200 nm). A proteinious layer is found between the nucleocapsid and envelop, which is well known as the tegument (Mocarski and Courcelle, 2001; Roizmann et al., 1992). The virus also contains a core protein viral DNA polymerase and virion structure (major capsid proteins, gp B, H and L (Alba et al., 2001), which are conserved among all families members. The genome of CMV is the largest among all herpes viruses (Dolan et al., 2004). It is a dsDNA genome with a length around 230-235kbp (Cha et al., 1996). Its linear genome contains two main regions with different length named Unique Long (UL) and Unique Short (US). Different internal repeated sequences are available. The genome structure can be represented as $a b-U_{L}-b^{\prime} a{ }^{\prime} c^{\prime}-U_{S}-c a$. in which, ba and b'a' donated $U_{L}$ and $\mathrm{U}_{\mathrm{S}}$ and $\mathrm{ca} / \mathrm{c}^{\prime} \mathrm{a}$ ' indicated the inverted repeats. The Presence of these internal sequences allows the genome regions to orientate, showing four isomers. 
Approximately, 220 genes (in wild type) are available in the genome which is named according to their location in the genome. Earlier studies done showed that more than 200 Open Reading Frames were found in both clinical isolates and laboratory strains (Murphy et al., 2003a; Murphy and Shenk, 2008; Murphy et al., 2003b; Yu et al., 2003b). In another report, 19 ORFs were deleted from laboratory strains during their adaption to grow in the fibroblast cell line (Cha et al., 1996). Most genes located in the UL are involved in viral structure and replication ( $\mathrm{Yu}$ et al., 2003b), while the US region contains specific genes that encode for immune evasion (Mocarski et al., 2007; Yu et al., 2003a).

\section{Infection Cycle}

CMV replication cycle takes place in the nucleus and cytoplasm. The replication cycle spans $48 \mathrm{~h}$ to $72 \mathrm{~h}$ in the fibroblast cell line (Browne et al., 2001). The following steps were recorded in the host nucleus: DNA synthesis, encapsidation, capsid assembly and initial tegumentaion (Mocarski et al., 2007), while other steps in the cytoplasm are essential for maturation and release (Das and Pellett, 2011; Das et al., 2007; Tandon and Mocarski, 2008).

The first step in the replication is attachment to cell receptor. Presence of different types of glycoproteins on virus envelop give the virus ability to invade a broad range of cells. Moreover, these glycoproteins can arrange in three main complexes $\mathrm{gCI}(\mathrm{gB}$ homodimer, gCII $(\mathrm{gM} / \mathrm{gN}), \mathrm{gCIII}(\mathrm{gH} / \mathrm{gL} / \mathrm{pO})$ and $\mathrm{gH} / \mathrm{gL} / \mathrm{pUL}(128,130$, $131 \mathrm{~A})$, thus the virus has ability to interact with many cellular receptors. Many receptors were reported to facilitate the virus entry to the cell such as Heparin sulphate proteoglycan (Petrik et al., 2007; Ryckman et al., 2006; Sinzger et al., 2008), cellular epidermal Growth Factors Receptor (GEFR) (Wang et al., 2003), intergin as co receptors ( $\beta 1, \beta 2$ intergens) (Feire et al., 2010; Isaacson et al., 2007; Soroceanu et al., 2008; Wang et al., 2005) and platelet-derived growth factor receptor- $\alpha$ (PDGFR $\alpha$ ) (Boyle and Compton, 1998). Comparison between clinical isolate and laboratory strains showed that laboratory adapted strains lost their ability to infect epithelial, endothelial and monocytemacrophages, which resulted in development of mutation in UL128, UL130 and UL 131(Cha et al., 1996; Dolan et al., 2004; Hahn et al., 2004). Following viral entry the viral envelope will fuse with the endosomal membrane, releasing the nucleocapsid and the teguments proteins in the cytoplasm and is mediated by glycoprotein complex gH/gL (Connolly et al., 2011). Next, the nucleocapsid is delivered to the nucleus, the main place for the virus replication steps. Both cellular microtubules and the motor system help in the delivery of the viral capsid into the nucleus (Radtke et al., 2010), mediated by pUL47 (Bechtel and Shenk, 2002) and pUL48 proteins. In addition, pUL69 can interact with the capsid and facilitate nucleocapsid translocation into the nucleus (Radtke et al., 2010).

The viral nucleic acid is then released and enters the nucleus through the nucleus pore to start its transcription to the mRNA and microRNAs (miRNA). The transcription of the viral genome is mediated by the cell RNA polymerase II in the presence of host transcription factors. The virus encodes for miRNA, which plays a special role in the control the gene expression in order to facilitate virus replication. During the productive infection, the transcription of the viral genes appears in three phases. There are intermediate early (IE or $\alpha)(0$ to $2 \mathrm{~h})$, early $(\mathrm{E}$ or $\beta)(24 \mathrm{~h})$ and late $(\mathrm{L}$ or $\gamma)(>24 \mathrm{~h})$ proteins (Stinski, 1978). The expressions of these genes start directly without stimulation from any synthesized protein (Rodems and Spector, 1998), under control of Major IE Promoter (MIEP) (Cherrington and Mocarski, 1989; Pizzorno et al., 1988). The first two proteins expressed are IE1 and IE2 (UL123 and UL122 gene products that were known as IE 72 and IE86). They play a role to get a suitable environment to support viral replication since they contain sequence specific DNA binding and activator domains (Bryant et al., 2000; Castillo and Kowalik, 2002; Mocarski and Courcelle, 2001; Nevels et al., 2004; Petrik et al., 2007; Song and Stinski, 2005; Stinski and Petrik, 2008). As IE proteins accumulate in the nucleus, their expression will be suppressed through the interaction between pp71 and Daxx which initiate the DNA replication (Cantrell and Bresnahan, 2005; Preston and Nicholl, 2006). The E proteins are classified as proteins $\beta 1$ (E) and $\beta 2$ (E-L), involved in the viral DNA synthesis, other nonstructural protein and immune response evasion (Mocarski and Courcelle, 2001). The DNA synthesis is carried in the special region of the nucleus known as nuclear replication compartments (known as nuclear domain 10, ND10) (Everett, 2006). The virus will synthesize six core proteins for replication (replication fork proteins) of viral DNA and includes UL44, UL54, UL57, UL102, UL105 and UL170 (Pari et al., 1993). The six core proteins along with four UL112-113 gene products and the trans activators form the replication compartment (Penfold and Mocarski, 1997). Another strand is built as fragmented strands (Okazaki fragments), where the new genome appears as concatmers. The new genome (special length) that encapsulate inside the procapsid is cut from the concatmers terminase during assembly step. One of the important proteins that require for the viral genome replication is UL84. This protein has nuclear import and export signals that allow it to shuttle easily between the nucleus and cytoplasm (Lischka et al., 2006; $\mathrm{Xu}$ et al., 2002). The protein was also reported to be likely a member of DExD/H box family of helicases and exhibits UTPase Activity (Colletti et al., 2005).

Some of the E proteins trigger the expression of late genes such as UL79, UL87 and UL95 (Isomura et al., 2011). The $\mathrm{L}$ proteins are classified as $\gamma 1$ and $\gamma 2$ and actually, they are structural proteins involved in the 
assembly and morphogenesis of new progeny virus (Mocarski and Courcelle, 2001). Some of the true late expression genes are U175 (gH), UL99 (pp28) and the middle transcription start site of UL44 (Kohler et al., 1994; Leach and Mocarski, 1989; McWatters et al., 2002; Winkler et al., 1994).

The virus assembly starts through both the precursor (pAP, pUL80.5) and protease precursor (pPR, pUL80a). Both of them will be eliminated from the mature capsid (Gibson et al., 1996). As translation of the protein is in the cytoplasm, procapsid formation begins in the cytoplasm where MCP interacts with pAP in a 1:1 stoichiometric ratio (Beaudet-Miller et al., 1996). This complex translocates into the nucleus which is the main site for the assembly. pAP plays a main role in the oligomerization and mediates the formation of hexons and pentons (Plafker and Gibson, 1998). These larger assemblies interact with $\mathrm{mCP}$ and $\mathrm{mC}-\mathrm{BP}$ to form the capsid precursor (Newcomb et al., 1999), which becomes decorated with SCP at the tips of the hexons in a process that completes the formation of capsids (Lai and Britt, 2003). pUL104 is located in one site on the capsid and it Forms a portal through which the viral DNA genome is loaded (Butcher et al., 1998). A new genome is detached from the concatamer through direct interaction of pUL56 and pUL89 (DNA terminase and cleavage/packaging enzyme), which bind to packaging (pac) sites at/or near the ends of replication and concatameric viral DNA to position the DNA for packaging into capsids at the protein portal (pUL104) (Thoma et al., 2006). Viral DNA is cleaved into unit lengths and packaged into capsids when the terminase (pUL56) arrives at the next pac site (Bogner et al., 1998; Scheffczik et al., 2002). The nucleocapsid leaves the nucleus through mechanisms well known as envelopment, de-envelopment and re-envelopment processes (dual envelopment) (Skepper et al., 2001). The particle will acquire the final envelope from the Golgi apparatus in special area known as viral assembly compartment (AuCoin et al., 2006; Das et al., 2007).

Latent infection was reported in the herpesviruses, where the viral genome forms a close circle DNA. This infection can appear in different types of cells (Davison et al., 2002; Fishman, 2013) such as bone marrow-derived myeloidprogenitor cells (Bego and St Jeor, 2006; Sinzger et al., 2008). Most of lytic gene expressions are shut down or downregulated through miRNA (Harris-Arnold et al., 2012). The reactivation of the virus was reported in people with suppression of the immune system (Dalen, 2002). The purpose of this infection is to help the virus to avoid some cellular defense mechanisms such as apoptosis of infected cells and production of alpha interferon (Ambagala and Cohen, 2007). Three possible pathways that lead to the establishment of latency have been proposed (Cheung et al.,
2006). First is failure to express the virus gene after entry, second is interruption of virus replication and thirdly, expression of latent genes instead of productive genes, which can be reactivated to produce an infectious virus (Mocarski, 1993).

\section{Routes of Transmission}

Virus is shed in different body secretions such as blood, saliva, breast milk, semen, urine and cervical secretion, close contact with these fluids is paramountin order to get infection (AAP, 2009; Stagno and Britt, 2006). CMV cannot be transmitted through aerosol transmission (McCluskey et al., 1996). The virus can also be sexually transmitted (Britt, 1996; Fowler and Pass, 2006) and also through hematogenous routes (Gilbert et al., 1989), where other blood cells play a role in virus distribution to different organs (Ibanez et al., 1991; Sinzger and Jahn, 1996; Sinzger et al., 1996). It was reported that vascular endothelial cells can break out from blood vessel and enter the blood stream (Chen et al., 2003; Grefte et al., 1993; Nerheim et al., 2004; Percivalle et al., 1993). Moreover, the uterine micro vascular endothelial cells can Transmit infection to the infant through cytotrophoblasts (Maidji et al., 2002).

\section{Complication Associated with HCMV Infection}

The distribution of the virus is high in most populations (60\%-100\%) (Razonable and Emery, 2004; Razonable and Paya, 2003). The immune system can control the infection successfully (Huang and Kowalik, 1993) and only mononucleosis was reported in less than 7\% of infected peoples (Alford et al., 1990; Taylor, 2003).

CMV infection is terrible in immunosuppressed transplant recipients, HIV patients and fetus of infected pregnant women (Buyck et al., 2010; Dollard et al., 2007; Freeman, 2009; Gandhi and Khanna, 2004; Steininger et al., 2006; Streblow et al., 2001; Tuthill et al., 2009). The most common disease cases reported in immune-competent patients are arthralgia, arthritis, ulcerative colitis, pneumonitis, hepatitis, asepticmeningitides and myocarditis (Gandhi and Khanna, 2004) fever with bone marrow suppression and tissue invasive disease (Razonable and Emery, 2004; Razonable and Paya, 2003). All these are in addition to upregulation of alloantigen's which led to acute or chronic allograft rejection (Razonable and Paya, 2005). In HIV patients, rentitis is the most common sign of CMV infection. Moreover, CMV mediates some vascularassociated diseases such atherosclerosis, restenosis and transplant vascular sclerosis (Streblow et al., 2001).

\section{Congenital Infection Associated with CMV}

CMV has been reported to be responsible for most birth deficits in recent time (Alford et al., 1990; Nassetta et al., 2009; Nichols and Boeckh, 2000; 
Volpe, 2008). The prevalence of infection depends on the socioeconomic statuses of the mothers. Infection rate is $50-60 \%$ in the middle and high socioeconomic status pregnant women and $70-85 \%$ in low socioeconomic status pregnant women (Malm and Engman, 2007; Trincado and Rawlinson, 2001). Fetus and newborn infants can be infected with CMV through one of three routes; vertical transmission, Intrapartuminfectionand postnatally (Boppana et al., 2001; Fowler et al., 2003; Staras et al., 2006). Approximately $30-40 \%$ of infections are trans-placentally acquired (Malm and Engman, 2007; Stagno, 2007; Stagno and Britt, 2006; Trincado and Rawlinson, 2001). The infection is high in fetus born from a mother with a high viremia (Harrison and Myers, 1990), which validates the presence of maternal antibody IgG (Maidji et al., 2006). The $\operatorname{IgG}$ facillate the virus transmission via transcytosis for the virus-IgG complex that is mediated by neonatal Fc Receptor (FcRn) on the surface of syncytiotrophoblasts (Attard-Montalto et al., 1993).

Approximately, 10-30\% of sero-positive women can develop congenital infection following infection with a new strain of CMV and $1-3 \%$ of this infections are transmitted to the fetus (Ahlfors et al., 1999; Boppana et al., 1999; Boppana et al., 2001; Kenneson and Cannon, 2007; Stagno et al., 1982). Reactivation of latent CMV infection during pregnancy was reported the most common source of fetus infected (Huang et al., 1980). However, out of 0.64\%-0.70\% neonates born with HCMV (Dollard et al., 2007; Kenneson and Cannon, 2007), only 11\%-12.7\% showed symptoms of infection at birth. As compared with another childhood diseases; Down syndrome, congenital infection with $\mathrm{CMV}$ is responsible for childhood disability. The mortality rate associated with symptomatic congenital infection is 20-30\% (Bailey and Toltzis, 2011; Malm and Engman, 2007) and is related to development of hepatic dysfunction, bleeding, disseminated intravascular coagulopathy or secondary bacterial infection (Malm and Engman, 2007). Intrapartum infection usually occurs at birth during exposure to infected cervical or vaginal fluid. Around 2$28 \%$ of infected mothers shed the virus in their vaginal secretions, resulting in infection of $50 \%$ of infants (Stehel and Sánchez, 2005). It has also been shown that $9-88 \%$ of seropositive women shed virus in their milk resulting in infection rate of $50-60 \%$ among infants (Hamprecht et al., 2008; Stehel and Sánchez, 2005). Infection resulting from blood transfusions have also been documented (AAP, 2009; Hamprecht et al., 2001; Kumar et al., 1984; Roizman et al., 1981; Spreu et al., 2006). It was reported that the level of both humeral and cellular immunity in women played a role in transmission the infection to the fetus. The titer and avalidity of maternal $\operatorname{IgG}$ also plays a major role in disease transmission (Lazzarotto et al., 1999; Nigro et al.,
2005). Moreover, the outcomes of congential infection depends on the time of infection, virus titer and virulence of virus strain (Bratcher et al., 1995; Choi and Hsiung, 1978; Griffith and Hsiung, 1980; Harrison and Myers, 1990; Kumar and Prokay, 1983). The most severe form of the disease was reported in the fetus when the infection takes place in the early stage of gestation (Barkovich and Lindan, 1994; Hayward et al., 1991; Twickler et al., 1993).

HCMV has the ability to cause congenital infection of the fetal brain during its developmental process, resulting in interference of the neocortical neuronal migration to the cortical plate (Malm et al., 2000; Sugita et al., 1991; van der Knaap et al., 2004), usually between the 12th and 24th week of gestation (Gressens, 2006). There is no intrapartum and postnatal infection in fully developed fetus, but in premature infants and low birth-weight new-borns, symptomatic illness including hepatitis, neutropenia and thrombocytopenia have been reported (Lombardi et al., 2010), as well as "sepsis-like" symptoms (Hamprecht et al., 2001). Another effect of CMV in newborns is Sensory Neural Hearing Defect (SNHD) (Pass, 2005), which is associated with the ability of the virus to induce labyrinthitis (Strauss, 1990). CMV enters the endolymph via the striavascularis (Bauer et al., 2005; Davis, 1981; Strauss, 1985; Sugiura et al., 2003). One third of cases of nonheredity SNHL in young children were reported during CMV infection (Adler, 2005; Fowler et al., 1992; Harris et al., 1984; Hicks et al., 1993; Morton and Nance, 2006; Williamson et al., 1990), particularly following intrauterine HCMV infection (Fowler and Pass, 2006; Morton and Nance, 2006; Ogawa et al., 2007). The condition can develop early at birth, where $5.2 \%$ are symptomatic or asymptomatic in neonates, or later in childhood in $15.4 \%$ of children (Dollard et al., 2007; Foulon et al., 2008; Fowler et al., 1997; Fowler and Pass, 2006; Isaacs and Moxon, 1999; Walter et al., 2008; Zhang et al., 2007).

\section{Is RCMV ALL-03 a Good Model to Study CMV?}

As it is well known, CMV has species specificity and HCMV cannot replicate in animals. The availability of a good model is very important to study HCMV persistence, pathogenesis and therapeutic modalities. Different non-human cytomegaloviruses were isolated in recent time (Ho, 1991). They can be divided into two groups; primates and non-primates CMV.

\section{Primate Models for CMV}

In primates $\mathrm{CMV}$, the most common models are Rhesus macaque CMV (RhCMV) (Asher et al., 1974) and Chimpanzee CMV (CCMV). Rhseus CMV was isolated from Rhesus macaque (Alcendor et al., 1993; 
Hansen et al., 2003). Its genome length of $221,459 \mathrm{bp}$ is quite shorter than that of HCMV genome (230-235kbp) (Cha et al., 1996) and there are no isomers associated with it like in HCMV genome (Hansen et al., 2003). The RhCMV genome encodes for 230-260 ORF (open reading frames) (Hansen et al., 2003), while the HCMV encodes for 220 genes in wild type but 19 genes are missing in the laboratory strains (Cha et al., 1996; Mocarski and Courcelle, 2001).

It was reported that $\mathrm{RhCMV}$ can cross the placenta (Lockridge et al., 1999) and induce the same CNS abnormalities as in human infection (Barry et al., 2006; Tarantal et al., 1998). The viral DNA was detected in the brain (Chang et al., 2002) and interacts with immature neuronal and glial cells migrating during neurodevelopmental process (Rakic, 1988). In addition, RhCMV is the most common model used to study antiviral drugs against CMV (North et al., 2004). It showed the same sensitivity to gancilovir, GCV kinase, UL97, benzimidazole nucleosides likeHCMV (Serabe et al., 1999; Swanson et al., 1998), which makesit a model of choice to study antiviral drugs.

Protection from viral diseases can be through development of an effective vaccine. Study of immune response toward RhCMV has also been done. Interestingly RhCMV gpB can be neutralized by antiHCMV antibodies which reflects the cross reactivity between both viruses. Moreover, the two encoded RhCMV pp65 have the ability to induce the same humoral and adaptive immune responses as in HCMV pp65 (Yue et al., 2006). Modification of the cellular immune response is one of important key features of the virus once in the immune system. RhCMV has three genes; Rh182, Rh183, Rh189encoding for major histocompatibility complex class I, which interacts with cellular mediated immunity (CD8+ T-cell). Similarly, RhCMV can block interferon response by expression of special gene product; Interferon Stimulated Genes (ISGs). All previous immune studies suggest RhCMV provides data for its use as a good model for HCMV vaccine development.

The CCMV resembles the second primates CMV. It has a genome with a length of $241,087 \mathrm{bp}$, which is longer than HCMV (Cha et al., 1996), but encodes for less number of genes (165 genes only) and also has no associated isomers (Davison et al., 2003; Hansen et al., 2003). It is very closely related to HCMV (Davison et al., 2003) and both primate models have been used to study the pathology and pathogenesis of HCMV especially in pregnant animals (Asher et al., 1974; Huff et al., 2003; Jones-Engel et al., 2006; Lockridge et al., 1999; Vogel et al., 1994).

Although both models resemble HCMV in terms of pathogenesis and infection, they are not used to study
HCMV for various reasons; cost and rarity of keeping chimpanzees for experimentation since they are protected by law as endangered animals (Davison et al., 2003), lack of aborted Rhesus monkey fetus or neonates from congenital infection to perform histopathological studies, rarity of a seronegative Rhesus animals to perform the experimental studies (Vogel et al., 1994) thus making it an unused model to study congenital CMV infection (Fowler et al., 2003). Moreover, absence of inbred and knockout animals make this model unpractical compared with small animals (Powers and Fruh, 2008). As the rate of congential infection with CMV in rhesus is very low, this model is sutable for study of pathogenesis of the virus and not its vertical transmission (Barry et al., 2006).

\section{Non Primate Models for CMV}

Various small animal models for propagation of CMV have been reported in literature. Even though these models have different genome structures compared to the human genome (McGregor et al., 2004; Rawlinson et al., 1996; Vink et al., 2000), they are useful regarding their small size, low cost, short life span, high productivity rate and ease of handling (Loh et al., 2006).

The most common CMV strains used in small animal studies are Murine CMV(MCMV) (Rawlinson et al., 1996), rat CMV (Maastricht strain, RCMV-M and English strain, RCMV-E) (Bruggeman et al., 1982; Priscott and Tyrrell, 1982) and guinea pig CMV (GPCMV) (Schleiss et al., 2008). They all have genome lengths smaller than that of HCMV, with the lowest GC content $(55 \%)$ in GPCMV and highest $(61 \%)$ in RCMV-M. All CMV models showed the same pathogenesis and pathogenicity as HCMV (Bruggeman et al., 1983; Dix et al., 2003; Katzenstein et al., 1983; Krmpotic et al., 2003; Mocarski et al., 1996; Pass, 2001; Reddehase et al., 2002; Reddehase et al., 1985; Shanley et al., 1993; Stals et al., 1990; Zhang and Atherton, 2002) with the exception of GPCMV, which is the only model that can cross the placenta (Choi and Hsiung, 1978; Markham and Hudson, 1936).

MCMV has a genome length of 230,278 bp, with a GC content of $58.7 \%$ and an approximately 170 ORFs out of which 78 have significant homology with HCMV. Murine animals are the first choice to study CMV infection due to their small size, well characterized animals with knock out genes, short gestationperiod (19$21 \mathrm{~d})$ and significantly greater litter size (10-12) of newborn pups. Unfortunately, there is no report yet about ability of MCMV to cross the placenta. Moreover, the structure of the placenta in this model is different from humans as the placenta consists of three layers which separate the fetus from the maternal circulation. This model has been used to study the brain following congenital infection by direct inoculation of the virus 
into the embryo or placenta ( $\mathrm{Li}$ and Tsutsui, 2000; Tsutsui, 1995; Tsutsui et al., 2005; Woolf et al., 2007). Although the virus cannot cross the placenta, it has shown abnormalities in the CNS and can be detected in different areas of the brain (Trgovcich et al., 1998), as well as the retina, where it induced retinitis (Zhang and Atherton, 2002). MCMV has been also used to study antiviral drugs such asganciclovir (Duan et al., 1998; Kern, 1991; Neyts et al., 1992; Smee et al., 1992; Smee et al., 1994) and CDV (Kern, 1991, 1999; Neyts et al., 1992).

RCMV is another small animal model used to study HCMV in vivo. Many strains of RCMV have been isolated (Bruggeman et al., 1982; Priscott and Tyrrell, 1982; Loh et al., 2003). RCMV-M has a genome size of $230,138 \mathrm{bp}$, with a $61 \% \mathrm{G}+\mathrm{C}$ content and single unique sequence flanked by 504-bp terminal direct repeats. High concentration of $\mathrm{G}+\mathrm{C}$ contents were found in the TRs $(76 \%)$ (Vink et al., 2000). It encode for 166 ORFs among which 133 among showed homology to HCMV and MCMV (McGregor et al., 2004; Rawlinson et al., 1996).

In contrast, the genome size of RCMV-E is 202,946 bp and it encodes for 140 ORF that showed homology to the MuHV-1, although they are almost equally divergent from both MuHV-1 and MuHV-2, 19 of them are unique and not available in other RCMV.

RCMV-M and RCM-E showed the same pathogenesis of HCMV but did not show any sign in immunocompetent rats except for death (Bruggeman et al., 1983; Bruggeman et al., 1985). Both models cannot cross the placenta and infect the fetus, hence they are not good models to study the congenital infection associated with HCMV. These models have been used to study antiviral drug (Stals et al., 1991; Stals et al., 1993) such as cidofavir (Stals et al., 1991; Stals et al., 1993) and both showed good pharmacokentics potential of the drug.

In contrast, RCMV ALL-03 resembles the last RCMV isolated and wasisolated in 2003 from the placenta and uterus of a rat (Loh et al., 2003). The virus can cross the Placenta just like the HCMV. The details of RCMV All-03 are discussed in next section.

GPCMV has a genome with a length of 232,678bp, excluding the terminal repeats. The $\mathrm{G}+\mathrm{C}$ content of the genome is $55 \%$ and the genome sequences showed that the virus is closer to primates than rodents (Schleiss et al., 2008). It is the only small animal model reported to cross the placenta. Guinea Pig has a similar placental structure to humans, where the placenta is a single hemochorial made up of a single trophoblast layer separating maternal and fetal circulations (Griffith et al., 1985; Kaufmann and Davidoff, 1977; Leiser and Kaufmann, 1994).Guinea pig has a long gestation period (65-70 days) and can be divided in to trimesters (Bia et al., 1983), but this is a time consuming process as compared with other small animals such as rats which have a gestation periods 21 days. In addition, they have limited number of pups (mostly 3) when compared with other small animals such as mice or rats. GPCMV model exhibit the same pathogenesis especially in the CNS inducing Sensory Neural Hearing Loss (SNHL) as seen in human CMV (Fukuda et al., 1988; Griffith et al., 1982). Previously, this model was used in vaccine development, immune response (Bia et al., 1984; Chatterjee et al., 2001; Griffith et al., 1985; Harrison et al., 1995) and treatment of Sensory Neural Hearing Loss (SNHL) and labyrinthitis with ganciclovir (Katano et al., 2007; Park et al., 2010; Woolf et al., 1988). Unfortunately, there was a report of development of resistance towards GCV (Fong et al., 1987), which is the most common drug used in the treatment of HCMV congenital infection. In other related studies, the toxicity of antiviral compounds which cannot be reflected by in vitro studies was evaluated using GPCMV. In vivo study with CDV was done with this model and it showed renal toxicity in the tested group (Bravo et al., 1993; Li et al., 1990), which was similar to that observed in humans.

\section{RCMV ALL-03 Model and Study of Congenital CMV Infection}

In 2003, a new small animal model for CMV was isolated (Loh et al., 2003) and referred to as RCMV ALL-03. The virus was isolated from the uterus and placenta, thus reflecting its ability to cross the placenta as in comparison to MCMV and previous rat model (RCMV-M and RCMV-E) (Fitzgerald et al., 1990; Priscott and Tyrrell, 1982). The virus was detected in different organs such as the uterus, placenta, embryo, fetus, salivary gland, lung, spleen and liver as in other models (Bruggeman et al., 1983; Bruggeman et al., 1985; Loh and Hudson, 1981; Priscott and Tyrrell, 1982; Stals et al., 1990). The virus showed its ability to replicate in immunosuppressed group and pregnant females (Loh et al., 2006) as reportedin HCMV (Gould and Mims, 1980). The genome size of RCMV ALL-03 is 197,958 bp with a GC content of $46.00 \%$. It encodes for 123 ORFs and showed close similarity (99\%) to the RCMV-E (MuHV-8) (Balakrishnan et al., 2015).

Approximately, 123 ORFs in RCMV ALL-03 were similar to RCMV-E, 111 ORFs were similar to the MuHV-1 and 107 were similar to RCMV-M (MuHV-2). However, only 72 ORFs were found in RCMV. The highest homology of ALL-03 to RCMV was seen in a089 with RCMV-E E89, RCMV-M R89 and HCMV UL89 (DNA packaging Terminase subunit). RCMV ALL-03 showed similarity to the following ORFs; ALL03 a025 (UL25), Ox-2 membrane glycol (immune evasion protein), ALL-03 a082 (UL82) tegument protein pp71, US family gene members; ALL-03 a139 (US22), ALL-03 a140 (US 23), ALL-03 a141 (US 24) 
(Balakrishnan et al., 2015). The virus also showed good homology to the IE1 and IE2 intermediate early proteins, which mediate CMV gene expression and lytic cycle. Furthermore, seven conserved cytomegalovirus structural proteins and 7 conserved tegument proteins are encoded by this strain. The virus also encodes for four immune evasion proteins (ALL-03_A125, ALL03_a138, ALL-03_a144, ALL-03_a154) which show similarity to RCMV-E.

Compared with GPCMV model, rat has a short gestation period which reduces the experimental time required for study in this animal. Additionally, the increased litter size is an added advantage in the rat unlike in the guinea pig.

Studying the ability of the CMV to spread to the brain and affect its development is very important in establishing how HCMV congenital infection progresses in the fetus during neonatal development. Although the RCMV ALL-03 was not present in the brain, heart, testes and ovary, it has the ability to replicate in brain endothelia cell line as was previously shown (Camalxaman et al., 2013). As it is well known, infection of the brain endothelial cells, which are the main cell of the blood brain barrier gave an insight into the mechanism of how the virus can cross the brain and cause CNS abnormalities (Fritschy et al., 1996; Power et al., 1990). Even though the previous studies on the pathogenesis of different models have not discussed the pathogenesis during pregnancy using only RCMV ALL-03, CMV infection have been shown to be reactive during pregnancy (Gould and Mims, 1980) as it is during immunosuppressive drug treatment (Loh et al., 2006).

\section{Conclusion}

The use of small animals as model to study HCMV has benefits as highlighted earlier due to their cost and unavailability of other animal models such as chimpanzees (Loh et al., 2006). Since the HCMV genome is most closely related to CCMV and RhCMV and most genes necessary for the viral replication are present in RCMV ALL-03 strain, this strain will be a good model to study the pathogenesis of HCMV especially in pregnant rats. Furthermore, since only three strains of this virus can cross the placenta (RhCMV, GPCMV and RCMV ALL-03) and most population of guinea pigs are either seropositive or resistant to GCV, RCMV (ALL-03) strain will be the best model suited for this purpose.

\section{Acknowledgement}

This study was supported by the Ministry of Higher Education Malaysia FRGS Grant No: 5524642. And
Universiti Putra Malaysia Grant No: 9428700. The authors wish to appreciate the technical assistance of Kamaruddin Isa Awang of Veterinary virology laboratory.

\section{Author's Contributions}

Ashwaq Ahmed Abdullah: Designed, conceptualized the write up and drafted the manuscript and critically revised the manuscript.

Krishnan Nair Balakrishnan: Helped in drafting and final alignment of the Manscript.

Yusuf Abba: Edited the Manuscript and improved the grammer and structure.

Faez Firdaus Jesse Abdullah: Supervised the edited of the Manuscript and improvement of grammer and structure.

Zeenatul Allaudin Nazariah: Supervised the design and write up of the manuscript.

Rasedee Abdullah: Supervised the design and write up of the manuscript.

Noordin Mohamed Mustapha: Supervised the design and write up of the manuscript.

Mohd-Azmi Mohd-Lila: Maked considerable contributions to conception, supervised the design of the work and write up the Manuscript.

All authors have read and approved the final manuscript.

\section{Ethics}

The authors have no conflict of interest to declare.

\section{References}

AAP, 2009. Cytomegalovirus Infection. In: Red Book: Report of the Committee on Infectious Diseases, Pickering, L.K., C.J. Baker, D.W. Kimberlin and S.S. Long (Eds.), American Academy of Pediatrics, Elk Grove Village, ISBN-10: 1581103069, pp: 275-280.

Adler, S.P., 2005. Congenital cytomegalovirus screening. Pediatric Infect. Dis. J., 24: 1105-1106.

Ahlfors, K., S.A. Ivarsson and S. Harris, 1999. Report on a long-term study of maternal and congenital cytomegalovirus infection in Sweden. Review of prospective studies available in the literature. Scand. J. Infect. Dis., 31: 443-457.

DOI: $10.1080 / 00365549950163969$

Alba, M.M., R. Das, C.A. Orengo and P. Kellam, 2001. Genomewide function conservation and phylogeny in the herpesviridae. Genome Res., 11: 43-54. PMID: 11156614

Alcendor, D.J., P.A. Barry, E. Pratt-Lowe and P.A. Luciw, 1993. Analysis of the rhesus cytomegalovirus immediate-early gene promoter. Virology, 194: 815-821.

DOI: $10.1006 /$ viro.1993.1323 
Alford, C.A., S. Stagno, R.F. Pass and W.J. Britt, 1990. Congenital and perinatal cytomegalovirus infections. Rev. Infect. Dis., 12: S745-753.

DOI: $10.1093 /$ clinids/12.Supplement_7.S745

Ambagala, A.P. and J.I. Cohen, 2007. Varicella-zoster virus IE63, a major viral latency protein, is required to inhibit the alpha interferon-induced antiviral response. J. Virol., 81: 7844-7851.

DOI: $10.1128 /$ jvi.00325-07

Asher, D.M., C.J. Gibbs Jr., D.J. Lang and D.C. Gajdusek, 1974. Persistent shedding of cytomegalovirus in the urine of healthy Rhesus monkeys. Exp. Biol. Med., 145: 794-801. DOI: $10.3181 / 00379727-145-37897$

Attard-Montalto, S.P., M.C. English, L. Stimmler and G.J. Snodgrass, 1993. Ganciclovir treatment of congenital cytomegalovirus infection: A report of two cases. Scand. J. Infect. Dis., 25: 385-388.

DOI: $10.3109 / 00365549309008515$

AuCoin, D.P., G.B. Smith, C.D. Meiering and E.S. Mocarski, 2006. Betaherpesvirus-conserved cytomegalovirus tegument protein ppUL32 (pp150) controls cytoplasmic events during virion maturation. J. Virol., 80: 8199-8210.

DOI: $10.1128 /$ jvi.00457-06

Bailey, J.E. and P. Toltzis, 2011. Perinatal Viral Infections. In: Neonatal-Perinatal Medicine: Diseases of the Fetus and Infant, Martin, R.J., A.A. Fanaroff and M.C. Walsh (Eds.), Elsevier/Mosby St. Louis, ISBN-10: 0323065457.

Balakrishnan, K.N., A.A. Abdullah, S.N. Camalxaman, Y.W. Quah and Y. Abba et al., 2015. Complete genome sequence of rat cytomegalovirus strain all03 (Malaysian strain). Genome Announcements. DOI: $10.1128 /$ genomeA.00451-15

Barkovich, A.J. and C.E. Lindan, 1994. Congenital cytomegalovirus infection of the brain: Imaging analysis and embryologic considerations. AJNR Am. J. Neuroradiol, 15: 703-715. PMID: 8010273

Barry, P.A., K.M. Lockridge, S. Salamat, S.P. Tinling and Y. Yue et al., 2006. Nonhuman primate models of intrauterine cytomegalovirus infection. ILAR J., 47: 49-64. DOI: 10.1093/ilar.47.1.49

Bauer, P.W., M. Parizi-Robinson, P.S. Roland and S. Yegappan, 2005. Cytomegalovirus in the perilymphatic fluid. Laryngoscope, 115: 223-225. DOI: 10.1097/01.mlg.0000154722.55044.fc

Beaudet-Miller, M., R. Zhang, J. Durkin, W. Gibson and A.D. Kwong et al., 1996. Virus-specific interaction between the human cytomegalovirus major capsid protein and the $\mathrm{C}$ terminus of the assembly protein precursor. J. Virol., 70: 8081-8088. PMID: 8892933
Bechtel, J.T. and T. Shenk, 2002. Human cytomegalovirus UL47 tegument protein functions after entry and before immediate-early gene expression. J. Virol., 76: 1043-1050.

DOI: $10.1128 / J V I .76 .3 .1043-1050.2002$

Bego, M.G. and S.S. Jeor, 2006. Human cytomegalovirus infection of cells of hematopoietic origin: HCMV-induced immunosuppression, immune evasion and latency. Exp. Hematol., 34: 555-570. DOI: 10.1016/j.exphem.2005.11.012

Bia, F.J., B.P. Griffith, C.K. Fong and G.D. Hsiung, 1983. Cytomegaloviral infections in the guinea pig: Experimental models for human disease. Rev. Infect. Dis., 5: 177-195.

DOI: $10.1093 /$ clinids/5.2.177

Bia, F.J., S.A. Miller, H.L. Lucia, B.P. Griffith and M. Tarsio et al., 1984. Vaccination against transplacental cytomegalovirus transmission: Vaccine reactivation and efficacy in guinea pigs. J. Infect. Dis., 149: 355-362.

DOI: $10.1093 /$ infdis/149.3.355

Bogner, E., K. Radsak and M.F. Stinski, 1998. The gene product of human cytomegalovirus open reading frame UL56 binds the Pac motif and has specific nuclease activity. J. Virol., 72: 2259-2264. PMID: 9499084

Boppana, S.B., K.B. Fowler, W.J. Britt, S. Stagno and R.F. Pass, 1999. Symptomatic congenital cytomegalovirus infection in infants born to mothers with preexisting immunity to cytomegalovirus. Pediatrics, 104: 55-60. PMID: 10390260

Boppana, S.B., L.B. Rivera, K.B. Fowler, M. Mach and W.J. Britt, 2001. Intrauterine transmission of cytomegalovirus to infants of women with preconceptional immunity. New Engl. J. Med., 344: 1366-1371. DOI: 10.1056/nejm200105033441804

Boyle, K.A. and T. Compton, 1998. Receptor-binding properties of a soluble form of human cytomegalovirus glycoprotein B. J. Virol., 72: 1826-1833. PMID: 9499033

Bratcher, D.F., N. Bourne, F.J. Bravo, M.R. Schleiss and M. Slaoui et al., 1995. Effect of passive antibody on congenital cytomegalovirus infection in guinea pigs. J. Infect. Dis., 172: 944-950. DOI: 10.1093/infdis/172.4.944

Bravo, F.J., L.R. Stanberry, A.B. Kier, P.E. Vogt and E.R. Kern, 1993. Evaluation of HPMPC therapy for primary and recurrent genital herpes in mice and guinea pigs. Antiviral Res., 21: 59-72. DOI: 10.1016/0166-3542(93)90067-S

Britt, W., 2008. Manifestations of human cytomegalovirus infection: Proposed mechanisms of acute and chronic disease. Curr. Topics Microbiol. Immunol., 325: 417-470. DOI: $10.1007 / 978-3-540-77349-8 \_23$ 
Britt, W.J., 1996. Vaccines against human cytomegalovirus: Time to test. Trends Microbiol., 4: 34-38. DOI: 10.1016/0966-842X(96)81503-4

Browne, E.P., B. Wing, D. Coleman and T. Shenk, 2001. Altered cellular mRNA levels in human cytomegalovirus-infected fibroblasts: Viral block to the accumulation of antiviral mRNAs. J. Virol., 75: $12319-12330$.

DOI: $10.1128 /$ jvi.75.24.12319-12330.2001

Bruggeman, C.A., W.M. Debie, G. Grauls, G. Majoor and C.P. van Boven, 1983. Infection of laboratory rats with a new cytomegalo-like virus. Arch. Virol., 76: 189-199. DOI: 10.1007/BF01311103

Bruggeman, C.A., H. Meijer, F. Bosman and C.P. van Boven, 1985. Biology of rat cytomegalovirus infection. Intervirology, 24: 1-9.

DOI: $10.1159 / 000149612$

Bruggeman, C.A., H. Meijer, P.H. Dormans, W.M. Debie and G.E. Grauls et al., 1982. Isolation of a cytomegalovirus-like agent from wild rats. Arch. Virol., 73: 231-241. DOI: 10.1007/BF01318077

Bryant, L.A., P. Mixon, M. Davidson, A.J. Bannister and T. Kouzarides et al., 2000. The human cytomegalovirus 86-kilodalton major immediate-early protein interacts physically and functionally with his tone acetyltransferase P/CAF. J. Virol., 74: 7230-7237. DOI: 10.1128/JVI.74.16.7230-7237.2000

Butcher, S.J., J. Aitken, J. Mitchell, B. Gowen and D.J. Dargan, 1998. Structure of the human cytomegalovirus B capsid by electron cryomicroscopy and image reconstruction. J. Structural Biol., 124: 70-76. DOI: $10.1006 /$ jsbi.1998.4055

Buyck, H.C., P.D. Griffiths and V.C. Emery, 2010. Human Cytomegalovirus (HCMV) replication kinetics in stem cell transplant recipients following anti-HCMV therapy. J. Clin. Virol., 49: 32-36.

DOI: $10.1016 /$ j.jcv.2010.06.018

Camalxaman, S.N., N.A. Zeenathul, Y.W. Quah, H.S. Loh and H. Zuridah et al., 2013. Establishment of rat brain endothelial cells susceptible to rat cytomegalovirus ALL-03 infection. Vitro Cell Dev. Biol. Anim., 49: 238-244. DOI: 10.1007/s11626-012-9553-5

Cantrell, S.R. and W.A. Bresnahan, 2005. Interaction between the human cytomegalovirus UL82 gene product (pp71) and hDaxx regulates immediate- early gene expression and viral replication. J. Virol., 79: 7792-7802. DOI: 10.1128/jvi.79.12.7792-7802.2005

Castillo, J. P. and T.F. Kowalik, 2002. Human cytomegalovirus immediate early proteins and cell growth control. Gene, 290: 19-34.

DOI: $10.1016 / \mathrm{S} 0378-1119(02) 00566-8$

Cha, T.A., E. Tom, G.W. Kemble, G.M. Duke and E.S. Mocarski et al., 1996. Human cytomegalovirus clinical isolates carry at least 19 genes not found in laboratory strains. J. Virol., 70: 78-83. PMID: 8523595
Chang, W.L., A.F. Tarantal, S.S. Zhou, A.D. Borowsky and P.A. Barry, 2002. A recombinant rhesus cytomegalovirus expressing enhanced green fluorescent protein retains the wild-type phenotype and pathogenicity in fetal macaques. J. Virol., 76: 9493-9504. DOI: $10.1128 /$ JVI.76.18.9493-9504.2002

Chatterjee, A., Harrison, C.J., W.J. Britt and C. Bewtra, 2001. Modification of maternal and congenital cytomegalovirus infection by anti-glycoprotein $\mathrm{b}$ antibody transfer in guinea pigs. J. Infect. Dis., 183: 1547-1553. DOI: 10.1086/320714

Chen, R., S. Xiong, Y. Yang, W. Fu and Y. Wang et al., 2003. The relationship between human cytomegalovirus infection and atherosclerosis development. Mol. Cell Biochem., 249: 91-96. DOI: 10.1023/A:1024759311013

Cherrington, J.M. and E.S. Mocarski, 1989. Human cytomegalovirus ie1 transactivates the alpha promoter-enhancer via an 18-base-pair repeat element. J. Virol., 63: 1435-1440. PMID: 2536844

Cheung, A.K.L., A. Abendroth, A.L. Cunningham and B. Slobedman, 2006. Viral gene expression during the establishment of human cytomegalovirus latent infection in myeloid progenitor cells. Biood, 108: 3691-3699. DOI: 10.1182/blood-2005-12-026682

Choi, Y.C. and G.D. Hsiung, 1978. Cytomegalovirus infection in guinea pigs. II. Transplacental and horizontal transmission. J. Infect. Dis., 138: 197-202. DOI: 10.1093/infdis/138.2.197

Colletti, K.S., Y. Xu, I. Yamboliev and G.S. Pari, 2005. Human cytomegalovirus UL84 is a phosphoprotein that exhibits UTPase activity and is a putative member of the DExD/H box family of proteins. J. Biol. Chem., 280: 11955-11960. DOI: $10.1074 /$ jbc.C400603200

Connolly, S.A., J.O. Jackson, T.S. Jardetzky and R. Longnecker, 2011. Fusing structure and function: a structural view of the herpesvirus entry machinery. Nature Rev. Microbiol., 9: 369-381. DOI: $10.1038 /$ nrmicro 2548

Dalen, A.B., 2002. Cytomegalovirus (CMV). In: A Practical Guide to Clinical Virology, Haaheim, L.R., J.R. Pattison and R.J. Whitley (Eds.), John Wiley and Sons, Chichester, ISBN-10: 0470844299, pp: 104-105.

Das, S. and P.E. Pellett, 2011. Spatial relationships between markers for secretory and endosomal machinery in human cytomegalovirus-infected cells versus those in uninfected cells. J. Virol., 85: 5864-5879. DOI: 10.1128/jvi.00155-11

Das, S., A. Vasanji and P.E. Pellett, 2007. Threedimensional structure of the human cytomegalovirus cytoplasmic virion assembly complex includes a reoriented secretory apparatus. J. Virol., 81: 11861-11869. DOI: $10.1128 /$ jvi.01077-07 
Davis, G. L., 1981. In vitro models of viral-induced congenital deafness. Am. J. Otol., 3: 156-160. PMID: 6272579

Davison, A.J., D.J. Dargan and N.D. Stow, 2002. Fundamental and accessory systems in herpesviruses. Antiviral Res., 56: 1-11. DOI: 10.1016/S0166-3542(02)00107-9

Davison, A.J., A. Dolan, P. Akter, C. Addison and D.J. Dargan et al., 2003. The human cytomegalovirus genome revisited: Comparison with the chimpanzee cytomegalovirus genome. J. General Virol., 84: 17-28. DOI: 10.1099/vir.0.18606-0

Dix, R.D., E.R. Podack and S.W. Cousins, 2003. Loss of the perforin cytotoxic pathway predisposes mice to experimental cytomegalovirus retinitis. J. Virol., 77: 3402-3408. DOI: 10.1128/JVI.77.6.3402-3408.2003

Dolan, A., C. Cunningham, R.D. Hector, A.F. HassanWalker and L. Lee et al., 2004. Genetic content of wild-type human cytomegalovirus. J. General Virol., 85: 1301-1312. DOI: 10.1099/vir.0.79888-0

Dollard, S.C., S.D. Grosse and D.S. Ross, 2007. New estimates of the prevalence of neurological and sensory sequelae and mortality associated with congenital cytomegalovirus infection. Rev. Med. Virol., 17: 355-363. DOI: 10.1002/rmv.544

Duan, J., W. Paris, P. Kibler, C. Bousquet and M. Liuzzi et al., 1998. Dose and durationdependence of ganciclovir treatment against murine cytomegalovirus infection in severe combined immunodeficient mice. Antiviral Res., 39: 189-197.

DOI: $10.1016 / \mathrm{S} 0166-3542(98) 00038-2$

Everett, R.D., 2006. Interactions between DNA viruses, ND10 and the DNA damage response. Cell Microbiol., 8: 365-374. DOI: 10.1111/j.1462-5822.2005.00677.x

Feire, A.L., R.M. Roy, K. Manley and T. Compton, 2010. The glycoprotein B disintegrin-like domain binds beta 1 integrin to mediate cytomegalovirus entry. J. Virol., 84: 10026-10037.

DOI: $10.1128 /$ jvi.00710-10

Fishman, J.A., 2013. Overview: Cytomegalovirus and the herpesviruses in transplantation. Am. J. Transplant, 13: 1-8. DOI: 10.1111/ajt.12002

Fitzgerald, N.A., J.M. Papadimitriou and G.R. Shellam, 1990. Cytomegalovirus-induced pneumonitis and myocarditis in newborn mice. Arch. Virol., 115: 75-88. DOI: 10.1007/BF01310624

Fong, C.K., S.D. Cohen, S. McCormick and G.D. Hsiung, 1987. Antiviral effect of 9-(1,3-dihydroxy2-propoxymethyl)guanine against cytomegalovirus infection in a guinea pig model. Antiviral Res., 7: 11-23. DOI: 10.1016/0166-3542(87)90035-0

Foulon, I., A. Naessens, W. Foulon, A. Casteels and F. Gordts, 2008. A 10-year prospective study of sensorineural hearing loss in children with congenital cytomegalovirus infection. J. Pediatrics, 153: 84-88. DOI: 10.1016/j.jpeds.2007.12.049
Fowler, K.B., F.P. McCollister, A.J. Dahle, S. Boppana and W.J. Britt et al., 1997. Progressive and fluctuating sensorineural hearing loss in children with asymptomatic congenital cytomegalovirus infection. J. Pediatrics, 130: 624-630. DOI: 10.1016/S0022-3476(97)70248-8

Fowler, K.B. and R.F. Pass, 2006. Risk factors for congenital cytomegalovirus infection in the offspring of young women: Exposure to young children and recent onset of sexual activity. Pediatrics, 118: e286-e292. DOI: $10.1542 /$ peds.2005-1142

Fowler, K.B., S. Stagno and R.F. Pass, 2003. Maternal immunity and prevention of congenital cytomegalovirus infection. J. Am. Med. Association, 289: 1008-1011. DOI: 10.1001/jama.289.8.1008

Fowler, K.B., S. Stagno, R.F. Pass, W.J. Britt and T.J. Boll et al., 1992. The outcome of congenital cytomegalovirus infection in relation to maternal antibody status. New Engl. J. Med., 326: 663-667. DOI: $10.1056 /$ nejm199203053261003

Freeman Jr., R.B., 2009. The 'indirect' effects of cytomegalovirus infection. Am. J. Transplant, 9: 2453-2458. DOI: 10.1111/j.1600-6143.2009.02824.x

Fritschy, J.M., S. Brandner, A. Aguzzi, M. Koedood and B. Luscher et al., 1996. Brain cell type specificity and gliosis-induced activation of the human cytomegalovirus immediate-early promoter in transgenic mice. J. Neurosci., 16: 2275-2282. PMID: 8601807

Fukuda, S., E.M. Keithley and J.P. Harris, 1988. Experimental cytomegalovirus infection: Viremic spread to the inner ear. Am. J. Otolaryngol., 9: 135-141. DOI: 10.1016/S0196-0709(88)80019-X

Gandhi, M.K. and R. Khanna, 2004. Human cytomegalovirus: Clinical aspects, immune regulationand emerging treatments. Lancet Infect. Dis., 4: 725-738. DOI: 10.1016/s1473-3099(04)01202-2

Gibson, W., M.K. Baxter and K.S. Clopper, 1996. Cytomegalovirus "missing" capsid protein identified as heat-aggregable product of human cytomegalovirus UL46. J. Virol., 70: 7454-7461. PMID: 8892863

Gilbert, G.L., K. Hayes, I.L. Hudson and J. James, 1989. Prevention of transfusion-acquired cytomegalovirus infection in infants by blood filtration to remove leucocytes. Neonatal Cytomegalovirus Infect. Stud. Group Lancet, 1: 1228-1231. DOI: 10.1016/S01406736(89)92330-1

Gould, J.J. and C.A. Mims, 1980. Murine cytomegalovirus: Reactivation in pregnancy. J. General Virol., 51: 397-400.

DOI: 10.1099/0022-1317-51-2-397 
Grefte, A., N. Blom, M. van der Giessen, W. van Son and T.H. The, 1993. Ultrastructural analysis of circulating cytomegalic cells in patients with active cytomegalovirus infection: Evidence for virus production and endothelial origin. J. Infect. Dis., 168: 1110-1118. DOI: 10.1093/infdis/168.5.1110

Gressens, P., 2006. Pathogenesis of migration disorders. Curr. Opin. Neurol., 19: 135-140.

DOI: $10.1097 / 01 . w c 0.0000218228 .73678 . e 1$

Griffith, B.P. and G.D. Hsiung, 1980. Cytomegalovirus infection in guinea pigs IV. Maternal infection at different stages of gestation. J. Infect. Dis., 141: 787-793. DOI: $10.1093 /$ infdis/141.6.787

Griffith, B.P., H.L. Lucia and G.D. Hsiung, 1982. Brain and visceral involvement during congenital cytomegalovirus infection of guinea pigs. Pediatrics Res., 16: 455-459.

DOI: $10.1203 / 00006450-198206000-00010$

Griffith, B.P., S.R. McCormick, C.K. Fong, J.T. Lavallee and H.L. Lucia et al., 1985. The placenta as a site of cytomegalovirus infection in guinea pigs. J. Virol., 55: 402-409. PMID: 2991565

Hahn, G., M.G. Revello, M. Patrone, E. Percivalle and G. Campanini et al., 2004. Human cytomegalovirus UL131-128 genes are indispensable for virus growth in endothelial cells and virus transfer to leukocytes. J. Virol., 78: 10023-10033.

DOI: $10.1128 /$ jvi.78.18.10023-10033.2004

Hamprecht, K., J. Maschmann, G. Jahn, C.F. Poets and R. Goelz, 2008. Cytomegalovirus transmission to preterm infants during lactation. J. Clin. Virol., 41: 198-205. DOI: 10.1016/j.jcv.2007.12.005

Hamprecht, K., J. Maschmann, M. Vochem, K. Dietz and C.P. Speer et al., 2001. Epidemiology of transmission of cytomegalovirus from mother to preterm infant by breastfeeding. Lancet, 357: 513-518. DOI: 10.1016/s0140-6736(00)04043-5

Hansen, S.G., L.I. Strelow, D.C. Franchi, D.G. Anders and S.W. Wong, 2003. Complete sequence and genomic analysis of rhesus cytomegalovirus. J. Virol., 77: 6620-6636. DOI: $10.1128 /$ JVI.77.12.6620-6636.2003

Harris-Arnold, A.G.C., S.L. Lambert, S.M. Krams and O.M. Martinez, 2012. Modulation of IL-10-Specific B cell MicroRNAs by Latent Membrane Protein 1 and Epstein-Barr Virus: 1734. Transplantation, 94: 369-369.

Harris, J.P., N.K. Woolf, A.F. Ryan, D.M. Butle and D.D. Richman, 1984. Immunologic and electrophysiological response to cytomegaloviral inner ear infection in the guinea pig. J. Infect. Dis., 150: 523-530. DOI: 10.1093/infdis/150.4.523

Harrison, C.J. and M.G. Myers, 1990. Relation of maternal CMV viremia and antibody response to the rate of congenital infection and intrauterine growth retardation. J. Med. Virol., 31: 222-228.

DOI: $10.1002 /$ jmv. 1890310309
Harrison, C.J., W.J. Britt, N.M. Chapman, J. Mullican and S. Tracy, 1995. Reduced Congenital Cytomegalovirus (CMV) infection after maternal immunization with a guinea pig CMV glycoprotein before gestational primary CMV infection in the guinea pig model. J. Infect. Dis., 172: 1212-1220. DOI: $10.1093 /$ infdis/172.5.1212

Hayward, J.C., D.S. Titelbaum, R.R. Clancy and R.A. Zimmerman, 1991. Lissencephaly-pachygyria associated with congenital cytomegalovirus infection. J. Child Neurol., 6: 109-114. DOI: $10.1177 / 088307389100600203$

Hicks, T., K. Fowler, M. Richardson, A. Dahle and L. Adams et al., 1993. Congenital cytomegalovirus infection and neonatal auditory screening. J. Pediatric, 123: 779-782. DOI: $10.1016 / \mathrm{S} 0022-3476(05) 80859-5$

Ho, M., 1991. Cytomegalovirus: Biology and Infection. 1st Edn., Springer US, ISBN-10: 978-1-4757-99422, pp: 440.

Huang, E.S. and T.F. Kowalik, 1993. The Pathogenicity of Human Cytomegalovirus: An Overview. In: Molecular Aspects of Human Cytomegalovirus Diseases, Becker, Y., G. Darai and E.S. Huang (Eds.), Springer-Verlag Berlin Heidelberg, ISBN-10: 978-3-642-84850-6, pp: 3-45.

Huff, J.L., R. Eberle, J. Capitanio, S.S. Zhou and P.A. Barry, 2003. Differential detection of B virus and rhesus cytomegalovirus in rhesus macaques FN1. J. General Virol., 84: 83-92. DOI: 10.1099/vir.0.18808-0

Ibanez, C.E., R. Schrier, P. Ghazal, C. Wiley and J.A. Nelson, 1991. Human cytomegalovirus productively infects primary differentiated macrophages. J. Virol., 65: 6581-6588.

Isaacs, D. and R. Moxon, 1999. Hand Book of Neonatal Infections: A Practical Guide. 1st Edn., Bailliere Tindall, ISBN-10: 0702024775, pp: 264.

Isaacson, M.K., A.L. Feire and T. Compton, 2007. Epidermal growth factor receptor is not required for human cytomegalovirus entry or signaling. J. Virol., 81: 6241-6247. DOI: 10.1128/jvi.00169-07

Isomura, H., M.F. Stinski T. Murata, Y. Yamashita and T. Kanda et al., 2011. The human cytomegalovirus gene products essential for late viral gene expression assemble into prereplication complexes before viral DNA replication. J. Virol., 85: 6629-6644.

DOI: $10.1128 /$ jvi.00384-11

Jones-Engel, L., G.A. Engel, J. Heidrich, M. Chalise and N. Poudel et al., 2006. Temple monkeys and health implications of commensalism, Kathmandu, Nepal. Emerging Infect. Dis., 12: 900-906. DOI: $10.3201 /$ eid1206.060030 
Katano, H., Y. Sato, Y. Tsutsui, T. Sata and A. Maeda et al., 2007. Pathogenesis of cytomegalovirus-associated labyrinthitis in a guinea pig model. Microbes Infect., 9: 183-191. DOI: $10.1016 /$ j.micinf.2006.11.004

Katzenstein, D.A., G.S. Yu and M.C. Jordan, 1983. Lethal infection with murine cytomegalovirus after early viral replication in the spleen. J. Infect. Dis., 148: 406-411. DOI: 10.1093/infdis/148.3.406

Kaufmann, P. and M. Davidoff, 1977. The guinea-pig placenta. Adv. Anatomy Embryol. Cell Biol., 53: 5-91. DOI: $10.1007 / 978-3-642-66618-6$

Kenneson, A. and M.J. Cannon, 2007. Review and metaanalysis of the epidemiology of Congenital Cytomegalovirus (CMV) infection. Rev. Med. Virol., 17: 253-276. DOI: 10.1002/rmv.535

Kern, E.R., 1991. Value of animal models to evaluate agents with potential activity against human cytomegalovirus. Transplant Proc., 23: 152-155. PMID: 1648821

Kern, E.R., 1999. Chapter 111-Animal Models for Cytomegalovirus Infection: Murine CMV. In: Handbook of Animal Models of Infection, Sande, M.A. (Ed.), Academic Press, Burlington, ISBN-10: 0080533558 pp: 927-934.

Kohler, C.P., J.A. Kerry, M. Carter, V. P. Muzithras and T.R. Jones et al., 1994. Use of recombinant virus to assess human cytomegalovirus early and late promoters in the context of the viral genome. J. Virol., 68: 6589-6597. PMID: 8083994

Krmpotic, A., I. Bubic, B. Polic, P. Lucin and S. Jonjic, 2003. Pathogenesis of murine cytomegalovirus infection. Microbes Infect., 5: 1263-1277.

DOI: 10.1016/j.micinf.2003.09.007

Kumar, M.L., G.A. Nankervis, I.B. Jacobs, C.B. Ernhart and C.E. Glasson et al., 1984. Congenital and postnatally acquired cytomegalovirus infections: Long-term follow-up. J. Pediatrics, 104: 674-679. DOI: 10.1016/S0022-3476(84)80942-7

Kumar, M.L. and S.L. Prokay, 1983. Experimental primary cytomegalovirus infection in pregnancy: timing and fetal outcome. Am. J. Obstet. Gynecol., 145: 56-60. PMID: 6295164

Lai, L. and W.J. Britt, 2003. The interaction between the major capsid protein and the smallest capsid protein of human cytomegalovirus is dependent on two linear sequences in the smallest capsid protein. J. Virol., 77: 2730-2735.

DOI: $10.1128 / J V I .77 .4 .2730-2735.2003$

Landolfo, S., M. Gariglio, G. Gribaudo and D. Lembo, 2003. The human cytomegalovirus. Pharmacol. Therapeutics, 98: 269-297.

DOI: $10.1016 / \mathrm{S} 0163-7258(03) 00034-2$
Lazzarotto, T., P. Spezzacatena, S. Varani, L. Gabrielli and P. Pradelli et al., 1999. Anticytomegalovirus (anti-CMV) immunoglobulin G avidity in identification of pregnant women at risk of transmitting congenital CMV infection. Clin. Diagn Lab Immunol., 6: 127-129. PMID: 9874675

Leach, F.S. and E.S. Mocarski, 1989. Regulation of cytomegalovirus late-gene expression: differential use of three start sites in the transcriptional activation of ICP36 gene expression. J. Virol., 63: 1783-1791. PMID: 2538657

Leiser, R. and P. Kaufmann, 1994. Placental structure: In a comparative aspect. Exp. Clin. Endocrinol., 102: 122-134. DOI: $10.1055 / \mathrm{s}-0029-1211275$

Li, R.Y. and Y. Tsutsui, 2000. Growth retardation and microcephaly induced in mice by placental infection with murine cytomegalovirus. Teratology, 62: 79-85. DOI: $\quad 10.1002 / 1096-9926(200008) 62: 2<79:: A I D-$ TERA3>3.0.CO;2-S

Li, S.B., Z.H. Yang, J.S. Feng, C.K. Fong and H.L. Lucia et al., 1990. Activity of (S)-1-(3-hydroxy-2phosphonylmethoxypropyl)cytosine (HPMPC) against guinea pig cytomegalovirus infection in cultured cells and in guinea pigs. Antiviral Res., 13: 237-252. DOI: 10.1016/0166-3542(90)90069-J

Lischka, P., C. Rauh, R. Mueller and T. Stamminger, 2006. Human cytomegalovirus UL84 protein contains two nuclear export signals and shuttles between the nucleus and the cytoplasm. J. Virol., 80: 10274-10280. DOI: 10.1128/jvi.00995-06

Lockridge, K.M., G. Sequar, S.S. Zhou, Y. Yue and C.P. Mandell et al., 1999. Pathogenesis of experimental rhesus cytomegalovirus infection. J. Virol., 73: 9576-9583. PMID: 10516066

Loh, H.S., M.L. Mohd-Azmi, K.Y. Lai, A.R. SheikhOmar and M. Zamri-Saad, 2003. Characterization of a novel rat cytomegalovirus (RCMV) infecting placenta-uterus of Rattus rattus diardii. Arch. Virol., 148: 2353-2367. DOI: 10.1007/s00705-003-0173-y

Loh, H.S., M.A. Mohd-Lila, S.O. Abdul-Rahman and L.J. Kiew, 2006. Pathogenesis and vertical transmission of a transplacental rat cytomegalovirus. Virol. J., 3: 1-14. DOI: 10.1186/1743-422X-3-42

Loh, L. and J.B. Hudson, 1981. Murine cytomegalovirus infection in the spleen and its relationship to immunosuppression. Infect. Immun., 32: 1067-1072.

Lombardi, G., F. Garofoli and M. Stronati, 2010. Congenital cytomegalovirus infection: Treatment, sequelae and follow-up. J. Maternal Fetal Neonatal Med., 23: 45-48. DOI: $10.3109 / 14767058.2010 .506753$

Maidji, E., S. McDonagh, O. Genbacev, T. Tabata and L. Pereira, 2006. Maternal antibodies enhance or prevent cytomegalovirus infection in the placenta by neonatal Fc receptor-mediated transcytosis. Am. J. Pathol., 168: 1210-1226. DOI: 10.2353 /ajpath.2006.050482 
Maidji, E., E. Percivalle, G. Gerna, S. Fisherand and L. Pereira, 2002. Transmission of human cytomegalovirus from infected uterine microvascular endothelial cells to differentiating/invasive placental cytotrophoblasts. Virology, 304: 53-69. DOI: 10.1006/viro.2002.1661

Malm, G. and M.L. Engman, 2007. Congenital cytomegalovirus infections. Seminars Fetal Neonatal Med., 12: 154-159.

DOI: $10.1016 /$ j.siny.2007.01.012

Malm, G., E.H. Grondahl and I. Lewensohn-Fuchs, 2000. Congenital cytomegalovirus infection: A retrospective diagnosis in a child with pachygyria. Pediatric Neurol., 22: 407-408.

DOI: $10.1016 / \mathrm{S} 0887-8994(00) 00126-0$

Markham, F.S. and N.P. Hudson, 1936. Susceptibility of the guinea pig fetus to the submaxillary gland virus of guinea pigs. Am. J. Pathol., 12: 175-182. PMID: 19970259

McCluskey, R., R. Sandin and J. Greene, 1996. Detection of airborne cytomegalovirus in hospital rooms of immuncompromised patients. J. Virol. Methods, 56: 115-118. DOI: 10.1016/0166-0934(95)01955-3

McGregor, A., F. Liu and M.R. Schleiss, 2004. Identification of essential and non-essential genes of the Guinea Pig Cytomegalovirus (GPCMV) genome via transposome mutagenesis of an infectious BAC clone. Virus Res., 101: 101-108.

DOI: 10.1016/j.virusres.2003.12.030

McWatters, B.J., R.M. Stenberg and J.A. Kerry, 2002. Characterization of the human cytomegalovirus UL75 (glycoprotein $\mathrm{H}$ ) late gene promoter. Virology, 303: 309-316.

DOI: $10.1006 /$ viro.2002.1614

Mocarski, E.S., 1993. Cytomegalovirus Biology and Replication. In: The Human Herpesviruses, Roizman, B., R. Whitley, C. Lopez (Eds.), Raven Press, New York, ISBN-10: 0781700248, pp: 173-226.

Mocarski, E.S. and C.T. Courcelle, 2001. Cytomegaloviruses and Their Replication. In: Fields' Virology, Knipe, D.M. and P.M. Howley (Eds.), Lippincott Williams and Wilkins, Philadelphia, ISBN-10: 0781718325 pp: 2629-2673.

Mocarski, E.S., G.W. Kemble, J.M. Lyle and R.F. Greaves, 1996. A deletion mutant in the human cytomegalovirus gene encoding IE1(491aa) is replication defective due to a failure in autoregulation. Proc. National Acad. Sci. USA, 93: 11321-11326. DOI: 10.1073/pnas.93.21.11321

Mocarski, E.S., T. Shenk and R.F Pass, 2007. Cytomegalovirus. In: Fields' Virology, Knipe, D.M. and P.M. Howley (Eds.), Lippincott Williams and Wilkins, Philadelphia, ISBN-10: 0781760607.

Morton, C.C. and W.E. Nance, 2006. Newborn hearing screening-a silent revolution. New Engl. J. Med., 354: 2151-2164. DOI: 10.1056/NEJMra050700
Murphy, E., I. Rigoutsos, T. Shibuya and T.E. Shenk, 2003a. Reevaluation of human cytomegalovirus coding potential. Proc. National Acad. Sci. USA, 100: 13585-13590. DOI: 10.1073/pnas. 1735466100

Murphy, E. and T.E. Shenk, 2008. Human Cytomegalovirus Genome. In: Human Cytomegalovirus, Shenk, T. and M. Stinski (Eds.), Springer Science and Business Media, Berlin, ISBN-10: 3540773495, pp: 1-19.

Murphy, E., D. Yu, J. Grimwood, J. Schmutz and M. Dickson et al., 2003b. Coding potential of laboratory and clinical strains of human cytomegalovirus. Proc. National Acad. Sci. USA, 100: 14976-14981. DOI: 10.1073/pnas.2136652100

Nassetta, L., D. Kimberlin and R. Whitley, 2009. Treatment of congenital cytomegalovirus infection: Implications for future therapeutic strategies. J. Antimicrobial Chemotherapy, 63: 862-867. DOI: $10.1093 / \mathrm{jac} / \mathrm{dkp} 083$

Nerheim, P.L., J.L. Meier, M.A. Vasef, W.G. Li and L. $\mathrm{Hu}$ et al., 2004. Enhanced cytomegalovirus infection in atherosclerotic human blood vessels. Am. J. Pathol., 164: 589-600. DOI: 10.1016/s00029440(10)63148-3

Nevels, M., W. Brune and T. Shenk, 2004. SUMOylation of the human cytomegalovirus 72 kilodalton IE1 protein facilitates expression of the 86-kilodalton IE2 protein and promotes viral replication. J. Virol., 78: 7803-7812.

DOI: 10.1128/JVI.78.14.7803-7812.2004

Newcomb, W.W., F.L. Homa, D.R. Thomsen, B.L. Trus and N. Cheng et al., 1999. Assembly of the herpes simplex virus procapsid from purified components and identification of small complexes containing the major capsid and scaffolding proteins. J. Virol., 73: 4239-4250. PMID: 10196320

Neyts, J., J. Balzarini, L. Naesens and E. De Clercq, 1992. Efficacy of (S)-1-(3-hydroxy-2phosphonylmethoxypropyl)cytosine and 9-(1,3dihydroxy-2-propoxymethyl)guanine for the treatment of murine cytomegalovirus infection in severe combined immunodeficiency mice. J. Med. Virol., 37: 67-71. DOI: 10.1002/jmv.1890370112

Nichols, W.G. and M. Boeckh, 2000. Recent advances in the therapy and prevention of CMV infections. J. Clin. Virol., 16: 25-40.

DOI: 10.1016/S1386-6532(99)00065-7

Nigro, G., S.P. Adler, R. La Torre and A.M. Best, 2005. Passive immunization during pregnancy for congenital cytomegalovirus infection. New Engl. J. Med., 353: 1350-1362.

DOI: $10.1056 /$ NEJMoa043337

North, T.W., G. Sequar, L.B. Townsend, J.C. Drach and P.A. Barry, 2004. Rhesus cytomegalovirus is similar to human cytomegalovirus in susceptibility to ßenzimidazole nucleosides. Antimicrobial Agents Chemotherapy, 48: 2760-2765.

DOI: $10.1128 /$ aac.48.7.2760-2765.2004 
Ogawa, H., T. Suzutani, Y. Baba, S. Koyano and N. Nozawa et al., 2007. Etiology of severe sensorineural hearing loss in children: Independent impact of congenital cytomegalovirus infection and $\mathrm{GJB}_{2}$ mutations. J. Infect. Dis., 195: 782-788.

DOI: $10.1086 / 511981$

Pari, G.S., M.A. Kacica and D.G. Anders, 1993. Open reading frames UL44, IRS1/TRS1and UL36-38 are required for transient complementation of human cytomegalovirus oriLyt-dependent DNA synthesis. J. Virol., 67: 2575-2582. PMID: 8386266

Park, A.H., T. Gifford, M.R. Schleiss, L. Dahlstrom and S. Chase et al., 2010. Development of cytomegalovirus-mediated sensorineural hearing loss in a Guinea pig model. Arch. Otolaryngol. Head Neck Surgery, 136: 48-53.

DOI: $10.1001 /$ archoto.2009.210

Pass, R.F., 2001. Cytomegalovirus. In: Fields Virology, Knipe, D.M., P.M. Howley (Eds.), LippincottWilliam and Wilkins, Philadelphia, pp: 2675-2706.

Pass, R.F., 2005. Congenital cytomegalovirus infection and hearing loss. Herpes, 12: 50-55. PMID: 16209862

Pass, R.F., C. Zhang, A. Evans, T. Simpson and W. Andrews et al., 2009. Vaccine prevention of maternal cytomegalovirus infection. New Engl. J. Med., 360: 1191-1199.

DOI: $10.1056 /$ NEJMoa0804749

Penfold, M.E. and E.S. Mocarski, 1997. Formation of cytomegalovirus DNA replication compartments defined by localization of viral proteins and DNA synthesis. Virology, 239: 46-61.

DOI: $10.1006 /$ viro.1997.8848

Percivalle, E., M.G. Revello, L. Vago, F. Morini and G. Gerna, 1993. Circulating endothelial giant cells permissive for Human Cytomegalovirus (HCMV) are detected in disseminated HCMV infections with organ involvement. J. Clin. Invest, 92: 663-670. DOI: $10.1172 /$ jci116635

Petrik, D.T., K.P. Schmitt and M.F. Stinski, 2007. The autoregulatory and transactivating functions of the human cytomegalovirus IE86 protein use independent mechanisms for promoter binding. J. Virol., 81: 5807-5818. DOI: 10.1128/jvi.02437-06

Pizzorno, M.C., P. O'Hare, L. Sha, R.L. LaFemina and G.S. Hayward, 1988. Trans-activation and autoregulation of gene expression by the immediate-early region 2 gene products of human cytomegalovirus. J. Virol., 62: 1167-1179. PMID: 2831379

Plafker, S.M. and W. Gibson, 1998. Cytomegalovirus assembly protein precursor and proteinase precursor contain two nuclear localization signals that mediate their own nuclear translocation and that of the major capsid protein. J. Virol., 72: 7722-7732. PMID: 9733808
Power, C., S.D. Poland, W.T. Blume, J.P. Girvin and G.P. Rice, 1990. Cytomegalovirus and Rasmussen's encephalitis. Lancet, 336: 1282-1284. DOI: $10.1016 / 0140-6736(90) 92965-\mathrm{K}$

Powers, C. and K. Fruh, 2008. Rhesus CMV: An emerging animal model for human CMV. Med. Microbiol. Immunol., 197: 109-115. DOI: $10.1007 / \mathrm{s} 00430-007-0073-\mathrm{y}$

Preston, C.M. and M.J. Nicholl, 2006. Role of the cellular protein hDaxx in human cytomegalovirus immediate-early gene expression. J. General Virol., 87: 1113-1121. DOI: 10.1099/vir.0.81566-0

Priscott, P.K. and D.A. Tyrrell, 1982. The isolation and partial characterisation of a cytomegalovirus from the brown rat, Rattus norvegicus. Arch. Virol, 73: 145-160. DOI: 10.1007/BF01314723

Radtke, K., D. Kieneke, A. Wolfstein, K. Michael and W. Steffen et al., 2010. Plus- and minus-end directed microtubule motors bind simultaneously to herpes simplex virus capsids using different inner tegument structures. PLoS Pathol., 6: e1000991- e1000991. DOI: 10.1371/journal.ppat.1000991

Rakic, P., 1988. Specification of cerebral cortical areas. Science, 241: 170-176.

DOI: $10.1126 /$ science. 3291116

Rawlinson, W.D., H.E. Farrell and B.G. Barrell, 1996. Analysis of the complete DNA sequence of murine cytomegalovirus. J. Virol., 70: 8833-8849. PMID: 8971012

Razonable, R.R. and V.C. Emery, 2004. Management of CMV infection and disease in transplant patients. Herpes, 11: 77-86. PMID: 15960905

Razonable, R.R. and C.V. Paya, 2003. Herpesvirus infections in transplant recipients: Current challenges in the clinical management of cytomegalovirus and Epstein-Barr virus infections. Herpes, 10: 60-65. PMID: 14759337

Razonable, R.R. and C.V. Paya, 2005. Infections and allograft rejection-intertwined complications of organ transplantation. Swiss Med. Wkly, 135: 571-573. PMID: 16333768

Reddehase, M.J., J. Podlech and N.K. Grzimek, 2002. Mouse models of cytomegalovirus latency: overview. J. Clin. Virol., 25: 23-36. DOI: 10.1016/S1386-6532(02)00087-2

Reddehase, M.J. F. Weiland, K. Munch, S. Jonjic and A. Luske et al., 1985. Interstitial murine cytomegalovirus pneumonia after irradiation: characterization of cells that limit viral replication during established infection of the lungs. J. Virol., 55: 264-273. PMID: 2991554

Rodems, S.M. and D.H. Spector, 1998. Extracellular signal-regulated kinase activity is sustained early during human cytomegalovirus infection. J. Virol., 72: 9173-9180. PMID: 9765464 
Roizman, B., L.E. Carmichael, F. Deinhardt, G. de-The and A.J. Nahmias et al., 1981. Herpesviridae. Intervirology, 16: 201-217.

DOI: $10.1159 / 000149269$

Roizmann, B., R.C. Desrosiers B. Fleckenstein, C. Lopez and A.C. Minson et al., 1992. The family Herpesviridae: An update. Arch. Virol., 123: 425-449. DOI: $10.1007 / \mathrm{BF} 01317276$

Ryckman, B.J., M.A. Jarvis, D.D. Drummond, J.A. Nelson and D.C. Johnson, 2006. Human cytomegalovirus entry into epithelial and endothelial cells depends on genes UL128 to UL150 and occurs by endocytosis and low-pH fusion. J. Virol., 80: 710-722. DOI: 10.1128/jvi.80.2.710-722.2006

Scheffczik, H., C.G. Savva, A. Holzenburg, L. Kolesnikova and E. Bogner, 2002. The terminase subunits pUL56 and pUL89 of human cytomegalovirus are DNA-metabolizing proteins with toroidal structure. Nucleic Acids Res., 30: 1695-1703. DOI: 10.1093/nar/30.7.1695

Schleiss, M.R., A. McGregor, K.Y. Choi, S.V. Date and $\mathrm{X}$. Cui et al., 2008. Analysis of the nucleotide sequence of the Guinea Pig Cytomegalovirus (GPCMV) genome. Virol. J., 5: 139-139.

DOI: $10.1186 / 1743-422 x-5-139$

Serabe, B.M., D.J. Murry, R. Dauser, J. Nuchtern and J. Durfee et al., 1999. Plasma and CSF pharmacokinetics of ganciclovir in nonhuman primates. Cancer Chemotherapy Pharmacol., 43: 415-418. DOI: 10.1007/s002800050916

Shanley, J.D., L. Biczak and S.J. Forman, 1993. Acute murine cytomegalovirus infection induces lethal hepatitis. J. Infect. Dis., 167: 264-269.

DOI: 10.1093/infdis/167.2.264

Sinzger, C., M. Digel and G. Jahn, 2008. Cytomegalovirus cell tropism. Curr. Topics Microbiol. Immunol., 325: 63-83. DOI: $10.1007 / 978-3-540-77349-8 \_4$

Sinzger, C. and G. Jahn, 1996. Human cytomegalovirus cell tropism and pathogenesis. Intervirology, 39: 302-319. PMID: 9130041

Sinzger, C., B. Plachter, A. Grefte, T.H. The and G. Jahn, 1996. Tissue macrophages are infected by human cytomegalovirus in vivo. J. Infect. Dis., 173: 240-245. DOI: 10.1093/infdis/173.1.240

Skepper, J.N., A. Whiteley, H. Browne and A. Minson, 2001. Herpes simplex virus nucleocapsids mature to progeny virions by an envelopment $\rightarrow$ deenvelopment $\rightarrow$ reenvelopment pathway. J. Virol., 75: 5697-5702.

DOI: $10.1128 /$ jvi.75.12.5697-5702.2001
Smee, D.F., J.L. Morris, J.A. Leonhardt, J.R. Mead and A. Holy et al., 1992. Treatment of murine cytomegalovirus infections in severe combined immunodeficient mice with ganciclovir, (S)-1-[3hydroxy-2-(phosphonylmethoxy)propyl]cytosine, interferonand bropirimine. Antimicrobial Agents Chemotherapy, 36: 1837-1842.

DOI: 10.1128/AAC.36.9.1837

Smee, D.F., S.T. Sugiyama and E.J. Reist, 1994. Nucleotide analogs related to acyclovir and ganciclovir are effective against murine cytomegalovirus infections in BALB/c and severe combined immunodeficient mice. Antimicrobial Agents Chemotherapy, 38: 2165-2168. DOI: 10.1128/AAC.38.9.2165

Song, Y.J. and M.F. Stinski, 2005. Inhibition of cell division by the human cytomegalovirus IE86 protein: Role of the p53 pathway or cyclin-dependent kinase 1/cyclin B1. J. Virol., 79: 2597-2603. DOI: $10.1128 /$ jvi.79.4.2597-2603.2005

Soroceanu, L., A. Akhavan and C.S. Cobbs, 2008. Platelet-derived growth factor- $\alpha$ receptor activation is required for human cytomegalovirus infection. Nature, 455: 391-395. DOI: 10.1038/nature07209

Spreu, J., T. Stehle and A. Steinle, 2006. Human cytomegalovirus- encoded UL16 discriminates MIC molecules by their $\alpha 2$ Domains. J. Immunol., 177: 3143-3149. DOI: 10.4049/jimmunol.177.5.3143

Stagno, S., 2007. Cytomegalovirus. In: Nelson Textbook of Pediatrics, Kliegman, R.M. (Eds.), Saunders, Philadelphia, ISBN-10: 1416024506, pp: 1377-1339.

Stagno, S. and W. Britt, 2006. Cytomegalovirus Infections. In: Infectious Diseases of the Fetus and Newborn Infant, Remington, J.S. (Eds.), Elsevier Saunders, Philadelphia, ISBN-10: 0721605370, pp: 739-781.

Stagno, S., R.F. Pass, M.E. Dworsky, R.E. Henderson and E.G. Moore et al., 1982. Congenital cytomegalovirus infection-the relative importance of primary and recurrent maternal infection. New Engl. J. Med., 306: 945-949.

DOI: 10.1056/nejm198204223061601

Stals, F.S., F. Bosman, C.P. van Boven and C.A. Bruggeman, 1990. An animal model for therapeutic intervention studies of CMV infection in the immunocompromised host. Arch. Virol., 114: 91-107. DOI: 10.1007/BF01311014

Stals, F.S., E. de Clercq and C.A. Bruggeman, 1991. Comparative activity of (S)-1-(3-hydroxy-2phosphonylmethoxypropyl)cytosine and 9-(1,3dihydroxy-2-propoxymethyl)guanine against rat cytomegalovirus infection in vitro and in vivo. Antimicrobial Agents Chemotherapy, 35: 2262-2266. DOI: 10.1128/AAC.35.11.2262 
Stals, F.S., A. Zeytinoglu, M. Havenith, E. de Clercq and C.A. Bruggeman, 1993. Rat cytomegalovirusinduced pneumonitis after allogeneic bone marrow transplantation: effective treatment with (S)-1-(3hydroxy-2-phosphonyl-methoxypropyl)cytosine.

Antimicrobial Agents Chemotherapy, 37: 218-223. DOI: 10.1128/AAC.37.2.218

Staras, S.A., S.C. Dollard, K.W. Radford, W.D. Flanders and R.F. Pass et al., 2006. Seroprevalence of cytomegalovirus infection in the United States, 1988-1994. Clin. Infect. Dis., 43: 1143-1151.

DOI: $10.1086 / 508173$

Stehel, E.K. and P.J. Sánchez, 2005. Cytomegalovirus Infection in the Fetus and Neonate. NeoRev., 6: e38-e45. DOI: 10.1542/neo.6-1-e38

Steininger, C., E. Puchhammer-Stockl and T. PopowKraupp, 2006. Cytomegalovirus disease in the era of Highly Active Antiretroviral Therapy (HAART). J. Clin. Virol., 37: 1-9.

DOI: $10.1016 /$ j.jcv.2006.03.005

Stinski, M.F., 1978. Sequence of protein synthesis in cells infected by human cytomegalovirus: Early and late virus-induced polypeptides. J. Virol., 26: 686701. PMID: 209215

Stinski, M.F. and D.T. Petrik, 2008. Functional Roles of the Human Cytomegalovirus Essential IE86 Protein. In: Human Cytomegalovirus, Shenk, T.E. and M.F. Stinski (Eds.), Springer Berlin Heidelberg, ISBN-10: 978-3-540-77349-8, pp: 133-152.

Strauss, M., 1985. A clinical pathologic study of hearing loss in congenital cytomegalovirus infection. Laryngoscope, 95: 951-962.

DOI: $10.1288 / 00005537-198508000-00014$

Strauss, M., 1990. Human cytomegalovirus labyrinthitis. Am. J. Otolaryngol., 11: 292-298. DOI: 10.1016/0196-0709(90)90057-3

Streblow, D.N., S.L. Orloff and J.A. Nelson, 2001. Do pathogens accelerate atherosclerosis? J. Nutr., 131: 2798S-2804S. PMID: 11584110

Sugita, K., M. Ando, M. Makino, J. Takanashi and N. Fujimoto et al., 1991. Magnetic resonance imaging of the brain in congenital rubella virus and cytomegalovirus infections. Neuroradiology, 33: 239-242. DOI: 10.1007/BF00588225

Sugiura, S., T. Yoshikawa, Y. Nishiyama, Y. Morishita and E. Sato et al., 2003. Detection of human cytomegalovirus DNA in perilymph of patients with sensorineural hearing loss using real-time PCR. J. Med. Virol., 69: 72-75. DOI: 10.1002/jmv.10263

Swanson, R., B. Eric and S.W. Wong, 1998. Characterization of rhesus cytomegalovirus genes associated with anti-viral susceptibility. Virology, 240: 338-348. DOI: 10.1006/viro.1997.8935

Tandon, R. and E.S. Mocarski, 2008. Control of cytoplasmic maturation events by cytomegalovirus tegument protein pp150. J. Virol., 82: 9433-9444. DOI: $10.1128 /$ jvi.00533-08
Tarantal, A.F., M.S. Salamat, W.J. Britt, P.A. Luciw and A.G. Hendrickx et al., 1998. Neuropathogenesis induced by rhesus cytomegalovirus in fetal rhesus monkeys (Macaca mulatta). J. Infect. Dis., 177: 446-450. DOI: $10.1086 / 514206$

Taylor, G.H., 2003. Cytomegalovirus. Am. Family Phys., 67: 519-524.

Thoma, C., E. Borst, M. Messerle, M. Rieger and J.S. Hwang et al., 2006. Identification of the interaction domain of the small terminase subunit pUL89 with the large subunit pUL56 of human cytomegalovirus. Biochemistry, 45: 8855-8863. DOI: $10.1021 / \mathrm{bi0600796}$

Trgovcich, J., E. Pernjak-Pugel, J. Tomac, U.H. Koszinowski and S. Jonjic, 1998. Pathogenesis of Murine Cytomegalovirus Infection in Mice. In: CMV-Related Immunopathology, Scholz, M., H.F. Rabenau, H.W. Doerr, J.J. Cinatl (Eds.), Karger Medical and Scientific Publishers, Basel, ISBN-10: 3805566026, pp: 42-53.

Trincado, D.E. and W.D. Rawlinson, 2001. Congenital and perinatal infections with cytomegalovirus. J. Paediatrics Child Health, 37: 187-192. DOI: $10.1046 /$ j.1440-1754.2001.00645.x

Tsutsui, Y., 1995. Developmental disorders of the mouse brain induced by murine cytomegalovirus: Animal models for congenital cytomegalovirus infection. Pathol. Int., 45: 91-102. DOI: $10.1111 / \mathrm{j} .1440-1827.1995 . t b 03428 . x$

Tsutsui, Y., I. Kosug and H. Kawasaki, 2005. Neuropathogenesis in cytomegalovirus infection: Indication of the mechanisms using mouse models. Rev. Med. Virol., 15: 327-345. DOI: $10.1002 /$ rmv. 475

Tuthill, M., F. Chen, S. Paston, H. De La Pena and S. Rusakiewicz et al., 2009. The prevention and treatment of cytomegalovirus infection in haematopoietic stem cell transplantation. Cancer Immunol. Immunotherapy, 58: 1481-1488. DOI: $10.1007 / \mathrm{s} 00262-009-0722-7$

Twickler, D.M., J. Perlman and M.C. Maberry, 1993. Congenital cytomegalovirus infection presenting as cerebral ventriculomegaly on antenatal sonography. Am. J. Perinatol., 10: 404-406. DOI: $10.1055 / \mathrm{s}-$ 2007-994773

van der Knaap, M.S., G. Vermeulen, F. Barkhof, A.A., Hart and J.G. Loeber et al., 2004. Pattern of white matter abnormalities at MR imaging: Use of polymerase chain reaction testing of Guthrie cards to link pattern with congenital cytomegalovirus infection. Radiology, 230: 529-536. DOI: $10.1148 /$ radiol.2302021459

Vink, C., E. Beuken and C.A. Bruggeman, 2000. Complete DNA sequence of the rat cytomegalovirus genome. J. Virol., 74: 7656-7665. DOI: $10.1128 / J V I .74 .16 .7656-7665.2000$ 
Vogel, P., B.J. Weigler, H. Kerr, A.G. Hendrickx and P.A. Barry, 1994. Seroepidemiologic studies of cytomegalovirus infection in a breeding population of rhesus macaques. Lab Anim. Sci., 44: 25-30. PMID: 8007656

Volpe, J.J., 2008. Neurology of the Newborn. 5th Edn., Elsevier Health Sciences, Philadelphia, ISBN-10: 1416039953, pp: 1094.

Walter, S., C. Atkinson, M. Sharland, P. Rice and E. Raglan et al., 2008. Congenital cytomegalovirus: association between dried blood spot viral load and hearing loss. Arch. Dis. Child Fetal Neonatal Edn., 93: F280-F285. DOI: 10.1136/adc.2007.119230

Wang, X., S.M. Huong, M.L. Chiu, N. Raab-Traub and E.S. Huang, 2003. Epidermal growth factor receptor is a cellular receptor for human cytomegalovirus. Nature, 424: 456-461. DOI: 10.1038/nature01818

Wang, X., D.Y Huang, S.M. Huong and E.S. Huang, 2005. Integrin $\alpha v \beta 3$ is a coreceptor for human cytomegalovirus. Nature Med., 11: 515-521. DOI: $10.1038 / \mathrm{nm} 1236$

Williamson, W.D., A.K. Percy, M.D. Yow, P. Gerson and F.I. Catlin et al., 1990. Asymptomatic congenital cytomegalovirus infection: Audiologic, neuroradiologicand neurodevelopmental abnormalities during the first year. Am. J. Dis. Child, 144: 1365-1368.

DOI: 10.1001/archpedi.1990.02150360091031

Winkler, M., S.A. Rice and T. Stamminger, 1994. UL69 of human cytomegalovirus, an open reading frame with homology to ICP27 of herpes simplex virus, encodes a transactivator of gene expression. J. Virol., 68: 3943-3954. PMID: 8189530

Woolf, N.K., D.V. Jaquish and F.J. Koehrn, 2007. Transplacental murine cytomegalovirus infection in the brain of SCID mice. Virol. J., 4: 1-16.

DOI: $10.1186 / 1743-422 \mathrm{X}-4-26$
Woolf, N.K., J.W. Ochi, E.J. Silva, P.A. Sharp and J.P. Harris et al., 1988. Ganciclovir prophylaxis for cochlear pathophysiology during experimental guinea pig cytomegalovirus labyrinthitis. Antimicrobial Agents Chemotherapy, 32: 865-872. DOI: 10.1128/AAC.32.6.865

$\mathrm{Xu}$, Y., K.S. Colletti and G.S. Pari, 2002. Human cytomegalovirus UL84 localizes to the cell nucleus via a nuclear localization signal and is a component of viral replication compartments. J. Virol., 76: 89318938. DOI: $10.1128 /$ JVI.76.17.8931-8938.2002

Yu, D., M.C. Silva and T. Shenk, 2003a. Functional map of human cytomegalovirus AD169 defined by global mutational analysis. Proc. National Acad. Sci. USA, 100: 12396-12401. DOI: 10.1073/pnas. 1635160100

Yu, D., S.C. Maria and T. Shenk, 2003b. Functional map of human cytomegalovirus AD169 defined by global mutational analysis. Proc. National Acad. Sci., 100: 12396-12401. DOI: 10.1073/pnas. 1635160100

Yue, Y., A. Kaur, S.S. Zhou and P.A. Barry, 2006. Characterization and immunological analysis of the rhesus cytomegalovirus homologue (Rh112) of the human cytomegalovirus UL83 lower matrix phosphoprotein (pp65). J. General Virol., 87: 777-787. DOI: $10.1099 /$ vir.0.81516-0

Zhang, M. and S.S. Atherton, 2002. Apoptosis in the retina during MCMV retinitis in immunosuppressed BALB/c mice. J. Clin. Virol., 25: S137-S147. DOI: $10.1016 / \mathrm{S} 1386-6532(02) 00102-6$

Zhang, X.W., F. Li, X.W. Yu, X.W. Shi and J.P. Zhang, 2007. Physical and intellectual development in children with asymptomatic congenital cytomegalovirus infection: A longitudinal cohort study in Qinba mountain area, China. J. Clin. 185. DOI: $10.1016 /$ j.jcv.2007.08.018 